Synthesis of Natural

Products and

Potential Drugs

\title{
Synthesis of AMG 837
}

Key words

AMG 837

GPR40 receptor agonist

asymmetric alkynylation

asymmetric substitution

iridium

allylic alcohols

potassium alkynyltrifluoroborates

TFA (0.025 equiv)

$\mathrm{Bu}_{4} \mathrm{NBr}(0.1$ equiv)

1,4-dioxane, $25^{\circ} \mathrm{C}, 6 \mathrm{~h}$

$67 \%(4.0 \mathrm{mmol}$ scale $)$<smiles>CC#C[C@H](CC(=O)O)c1ccc(OCc2cccc(-c3ccc(C(F)(F)F)cc3)c2)cc1</smiles>

\begin{tabular}{c} 
Jones oxidation \\
\hline $0 \%$ C to r.t., $1 \mathrm{~h}$ \\
$82 \%(38 \mu \mathrm{mol}$ scale $)$
\end{tabular}

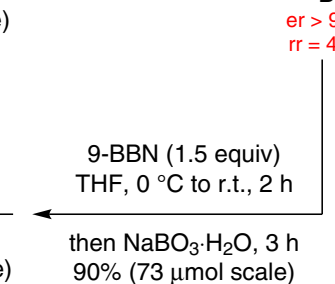

Scope of the enantioselective allylic alkynylation of aromatic allylic alcohols:<smiles>C=CC(C#Cc1ccccc1)c1ccc(I)cc1</smiles>

$62 \%(\mathrm{rr}>50: 1)$ $>99 \%$ ee<smiles>C=CC(C#CC(=C)C)c1ccccc1</smiles>
$>99 \%$ ee<smiles>C=CC(C#Cc1ccccc1)c1ccc(C=O)cc1</smiles>

$52 \%(\mathrm{rr}>50: 1)$ $>99 \%$ ee

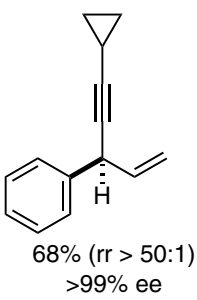<smiles>C=CC(C#Cc1ccccc1)c1ccccc1OC</smiles>

$89 \%(r r>50: 1)$ $99 \%$ ee<smiles>C=C[C@H](C#Cc1ccsc1)c1ccccc1</smiles><smiles>C=CC(C#Cc1ccccc1)c1ccsc1</smiles>

$96 \%(r r>50: 1)$ $>99 \%$ ee

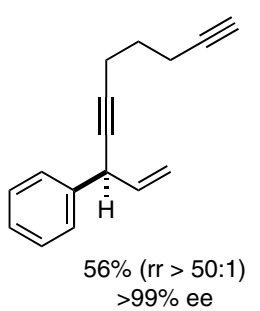

Significance: A new versatile method for the iridium-catalyzed asymmetric substitution of racemic allylic alcohols is exemplified by the depicted synthesis of AMG 837, a GPR40 receptor agonist that is of interest for the treatment of type 2 diabetes.
Comment: The allylic alkynylation (27 examples) typically provides excellent branched-to-linear regioselectivity ( $r r>50: 1)$ and high enantioselectivity ( $\geq 99 \%)$. The scope of the allylic alkynylation was explored using 12 allylic alcohols and 15 potassium alkynyltrifluoroborates.

SYNFACTS Contributors: Philip Kocienski

Synfacts 2013, 9(10), 1033 Published online: 17.09.2013

Dol: 10.1055/s-0033-1339715; Reg-No.: K05513SF 